\title{
The Indigenisation Policy and Economic Emancipation in Zimbabwe: A Case Study of the Zimunya-Marange Communities
}

\author{
Zvavahera Promise (Corresponding author) \\ Faculty of Commerce, Reformed Church University, Zimbabwe \\ E-mail: promisezvavahera59@gmail.com
}

Tel: 263-773-471-703/263-4-706-515

Chigora Farai

Catholic University of Zimbabwe, Zimbabwe

E-mail: fchigora@yahoo.com

Tandi Roselyn

Catholic University of Zimbabwe, Zimbabwe

E-mail: rtandi@cuz.ac.zw

Received: August 23, 2018 Accepted: September 28, 2018 Published: Nov. 22, 2018

doi:10.5296/bmh.v6i2.13954 URL: http://dx.doi.org/10.5296/bmh.v6i2.13954

\begin{abstract}
This study sought to evaluate the impact of the Indigenisation Policy on the socio-economic emancipation of rural communities in Zimbabwe. A case study approach was taken focusing on the Marange and Zimunya communities in Manicaland Province of Zimbabwe, where diamonds are being mined. Both qualitative and quantitative research methodologies were applied to get a balanced view from these two communities on their socio-economic improvement because of the mining of diamonds, which are a valuable natural resource found in these two communities. Purposive sampling was applied to come up with the sample of senior politicians and traditional leaders. Two Focus groups were formed in the two
\end{abstract}




\section{Macrothink}

Business and Management Horizons

ISSN 2326-0297

2018, Vol. 6, No. 2

communities. The study established that the five diamond mining companies doing business in the two communities had failed to honour their pledges of contributing USD10 million each towards the development of the two communities. Only USD400 000 was contributed by two mining companies at the time of the study. Ninety five percent $(95 \%)$ of the respondents reported that there were no projects that were being implemented to benefit the local communities. It was therefore, concluded that there was limited socio-economic empowerment of the Marange-Zimunya communities by the diamond mining companies. The study recommended the intervention by the Government in order for these mining companies to honour their pledges by coming up with empowerment projects and also by allowing the two communities to have shares in these companies so that they could be economically empowered.

Keywords: indigenisation policy, communities, economic emancipation, foreign organisation 


\section{Introduction}

At independence in 1980, the Government of Zimbabwe inherited a dual economy that was dominated by non-indigenously owned companies. A few whites owned most of the factors of production and the blacks were regarded as cheap and semi-skilled labour in the white owned enterprises (Matthew \& Gidigbi, 2017). The challenge of the Government soon after independence was to remove barriers and limitations for the indigenous Zimbabweans to enter into the mainstream economy. This became the basis for the creation of the Community Share Ownership Trusts (CSOTs), through the then Ministry of Youth, Indigenisation and Economic Empowerment. This also witnessed the development and application of the Indigenisation and Economic Act with the view of empowering and uplifting the less economically empowered Zimbabweans. It is estimated that about $70 \%$ of the country's population lives in the rural areas and survive mainly on the exploitation of natural resources and subsistence farming (Zimbabwe National Statistics Agency, 2015). The Indigenisation and Economic Empowerment Act sought to include all indigenous Zimbabweans, especially the rural communities into the mainstream economy through the provision of appropriate infrastructure such as schools, roads, clinics, dams, rural electrification, irrigation schemes and equity holding in businesses exploiting natural resources throughout the country. Zimbabwe is endowed with vast minerals and other natural resources such as wildlife and forestry.

\section{Literature Review}

Economic emancipation is a deliberate effort by the government to economically, politically and socially empower the less privileged so that they can participate in the mainstream economy. For this to happen, good corporate governance and political stability are key. There need is to develop and implement policies that support economic empowerment of groups that where left out of the mainstream economy before 1980. Economic empowerment broadly means the increase in the spirit, politics, social or economic strength of individuals and communities. Economic empowerment can also refer to how money is earned and spent by communities through various socio-economic initiatives (The Economist, 2007). Governments have the responsibility to empower their own people so that they can become self-reliant and contribute to the development of their economies. South Africa introduced the Black Economic Empowerment (BEE) as a deliberate programme aiming at empowering poor people who were disadvantaged before the country got its independence. The policy included Indians, Blacks and Chinese who were in South Africa before 1994 (South Africa Economy Watch, 2008). Economic marginalisation refers to the second economy where the majority were blacks categorised before independence. Secondary economy means high inequality in terms of distribution of wealth. It is evidenced by extreme poverty, diseases, wars and social alienation and civil unrest (Philip, 2011). Phillip (2011) avers that the inequalities in South Africa are based on the following:

Spatial inequality: the legacy of the 1913 Land Act, Bantustans and apartheid cities, and the impacts of recent policies, looking at rural development, skewed agriculture patterns, and the scope for payment for environmental services to create rural employment; 
$>$ Inequality in the development of human capital: including education and health; and

$>$ The structure of the economy: its impacts on unemployment and local economic development, including competition issues, small enterprise, the informal sector, value chains and labour markets.

A lot of interest and debate has been raised concerning Africa's position on strategies to be implemented to emancipate her economy. The interesting part is that some of the strategies being implemented by Africa today have failed in some countries. These prescriptive policies have spelt social and economic doom for the continent (Eshun, 2017). Most of these policy approaches and prescriptions haver failed to produce the desired socio-economic outcomes.

Mereko (2017) indicates that for economic emancipation to be successful there is need for the Government of South Africa to support the Black Empowerment move. Evidence reveals that Black Economic Empowerment in South Africa is being constrained by corruption, fraud, mismanagement, poor accountability, lack of monitoring and evaluation, difficulties in registering companies under BEE, lack of demand management and gross incompetence of public officials across municipalities. These obstacles have hindered the capacity of BEE to become an economic imperative aimed at redressing past imbalances (Shava, 2016). According to Marazanye (2016), the majority of the populace in Zimbabwe was empowered through land redistribution. However, the agriculture sector has been affected since most of the beneficiaries do not have the skill or the desire to be farmers. Joseph (2017) believes that the Fast Land Reform Programme in Zimbabwe further deteriorated the economy.

The Zimbabwean economic empowerment policy in trying to address the political and socio-economic imbalances created a size fit all approach which proved to be flawed. The policy deterred investment and many white owned companies closed business (Magure, 2013). Rural communities in Zimbabwe have the potential to change their own economic fortunes, as well as that of their families and their country if they are economically empowered. Work done by most rural communities is undervalued to the extent that their wealth is not accounted for in the Gross Domestic Product (GDP). Unequal opportunities and distribution of wealth between the minority (Whites) and the (Blacks) majority hampered indigenous blacks to uplift themselves from poverty and gain more options to improve their lives. These serious imbalances have led to the slow economic growth for the majority of the people (Golla, Malhotra, Nanda, \& Mehra, 2011).

Zimbabwe has been faced with high levels of poverty and unemployment since the year 2000 when the country embarked on the Fast Land Reform Programme to economically empower the black majority. On the other hand, the performance of the economy has been giving in since the late 1980s due to inconsistences in polices implementation, increased government expenditure, international relations and sanctions imposed on the country by the West (Kanyenze \& Kondo, 2011). The Economist (2007) estimated that unemployment rate in Zimbabwe stood at $80 \%$ in 2007 . This was attributed to the poor-performance by the manufacturing industry and a host of other factors and failure to recognise the contribution by the informal sector to the gross domestic product (GDP). Since the unemployment rate was no longer bearable, the Government then proposed the 2007 Empowerment Bill which was then 
passed into law in 2008 (The World Factbook, 2018). However, the introduction of this law was met with mixed reactions as it was regarded to be favouring certain sections of the population.

The Indigenisation and Empowerment Act (Chapter 14:33) is now administered by the Ministry of Women Affairs, Community Small and Medium Enterprise Development. The Act deals with Foreign companies doing business in Zimbabwe with an asset value of or above USD500 000 (Sections 3 and 4) tapping on natural resources. A business according to this Act is any entity, which is set up for profit making purposes. Charitable organisations do not fall under the Act. Any individuals who were economically disadvantaged before independence in 1980, are covered by the Act. The Act does not discriminate against race, colour or creed. Blacks, Coloureds, Indians and Chinese are covered by the Act. According to the Act, communities where these companies are operating from should get at least $10 \%$ of shares so that they are economically empowered. It should be noted that the Act has a historical background. The Government came up with a position at independence that foreign companies operating in Zimbabwe through extracting natural resources should cede $51 \%$ of their shares to the locals as a way of empowering them. This was supposed to apply to those companies, which would venture into mining, agriculture and exploitation of other natural resources. The Government shelved this idea for reasons not documented. What is interesting is for these companies to cry foul yet the position of the new Government in 1980 made it clear. Since then nothing was done by the Government to make sure that this post-independence policy was implemented to benefit the majority indigenous Zimbabweans (The Zimbabwe independent, 2014).

It has been noted with great concern that Sub-Saharan Africa is in abject poverty yet it boosts of huge deposits of natural resources including minerals, much of it untapped. What is also noted is that these communities also withstand the worst of environmental degradation without any compensation (Mawowa, 2013). From the Zimbabwean perspective, the locals should own $51 \%$ shares, $10 \%$ should be ceded to the local communities through a Community Share Ownership Trust (CSOT), and another $10 \%$ should be made available to the employees. However, when the Government introduced this scheme, the world and the opposition parties in Zimbabwe viewed it as a political gimmick, whereby they felt the ruling party, ZANU-PF was vote buying. The ruling party has been accused of running down the economy by proposing and implementing unfavorable policies for investors. Further to this, the Government has also been accused of looting the diamonds in Chiyadzwa, and evidence is that the former President admitted that 15 billion from diamond sales in Chiyadzwa disappeared. What is of interest is that no one has been linked or arrested concerning the missing money (Mawowa, 2013).

Due to the poor performance of the economy, the former Minister of Finance had proposed that Zimbabwe be regarded as a highly indebted poor country (HIPC) and the proposal was highly rejected by other Senior Government Officials as they did not want to be exposed. The idea of declaring the country highly indebted and poor was to facilitate the writing off the 6 billion debt for the country (Debt Relief under the Heavily Indebted Poor Countries Initiative, 2015). If this had been granted, Zimbabwe could have been getting financial assistance from the 
World Bank, the International Monetary Fund, and other financial institutions in order to revive the economy. The IMF through the Reduction Poverty Programme helped other HIPC Countries cancel their debts (World Bank, 2006). Zambia, Malawi, Ethiopia, Mali and Uganda among other countries benefited from this programme (International Monetary Fund, 2007).

In a study that was carried out by Makina (2009), it was noted that there is limited financial support from the local financial markets and direct foreign investment. In this regard, the Indigenisation and Economic Empowerment Act was found to be contrary to the the spirit of foreign investment. This was found to be leading to investment phobia which is not good for an economy which is in a bleeding state. Instead of offering attractive incentives, the Indigenisation and Economic Empowerment Act was found to be offering disincentives to foreign investors and financial firms. Munzara (2015) indicated that investors were not comfortable with the current setup that was not in the spirit of good corporate governance, the reason being that the government was putting up boards with high allowances and other incentives. Further to that, Gono (2013) avers that foreign financial institutions were not comfortable to invest in organisations they did not have control over since the government and locals were the major shareholders.

\subsection{Features of a Community}

In terms of having targeted interventions a community is characterised by the following:

$>$ Is constituted by a group of people living in a particular local area;

$>$ Collective ownership of natural capital (natural resources); and

$>$ Have common objectives and goals to achieve.

The objectives of the Community Share Ownership Schemes/ Trusts are as follows:

$>$ To empower local communities through exploitation of their natural resources;

$>$ Participation of poor rural communities in the mainstream economy;

Total inclusion of rural communities in the mainstream economy; and

$>$ Have shares in companies operating in their communities (Mawowa, 2013).

The Ministry of Youth, Indigenisation and Economic Empowerment established the CSOTs in some Rural Districts in which natural resources are being exploited by companies referred to as qualifying businesses. The Trusts are registered by the Deeds Office. The Board of Trustees is composed of all Chiefs in the Rural District Council, the District Administrator, Rural District Chief Executive Officer, the Chairperson, Head of Youth Affairs, the disabled and the qualifying businesses. There is a strong feeling among Zimbabweans that CSOTs if well implemented, have the ability of driving the Agenda for Sustainable Socio-Economic Transformation (Zim Asset). This is a call for all stakeholders to make sure that concerted efforts are made by all towards empowering the society (Zim Asset, 2013). 


\section{Objectives}

The specific objectives of the study were to:

1) Evaluate the impact of Community Share Ownership Schemes/ Trusts on economically empowering the Zimunya-Marange communities.

2) Identify projects initiated by communities through the financial pledges made by the companies operating in the Zimunya-Marange communities.

3) To identify the challenges in implementing the programme.

4) Recommend ways of overcoming the identified challenges.

\section{Research Methodology}

Quantitative and qualitative research methodologies were applied in this research. In-depth interviews and focus group discussion were used to solicit information from the respondents. The approach was appropriate since the researcher was dealing with the respondents' views and experiences on the implementation of the Community Ownership Trust Schemes. The idea behind using these two methodologies was also for triangulation purposes.

\subsection{Population and Sample}

All Traditional leaders, politicians, senior government officials, senior management of the five companies and all residents of the Zimunya-Marange communities made the population of the study. The population of the study was one thousand five hundred (1 500). Purposive sampling was applied to come up with the sample. The reason for purposive sampling was for the researchers to select participants they felt could provide valuable data. Two focus groups with fifteen participants each, four traditional leaders, two politicians and four Senior Government Officials made the sample. The sample of the study was therefore forty (40).

\subsection{Interviews}

Interviews were conducted with traditional leaders, two senior government officials from the Department of Youth Affairs, two politicians from these two communities and ten senior managers from the mining companies. The idea of carrying out in-depth interviews with these participants was to get the real issues and understanding the challenges which were being confronted by these two communities and the mining companies. The idea of using FDGs and interviews was to validate data from other groups in order to make appropriate comprehensive recommendations to the Government and other stakeholders. The same interview guide was used for the key informants.

\subsection{Findings}

Documentary evidence showed that 58 CSOTs were registered in some Rural Districts with companies exploiting natural resources in the respective communities. Trusts were officially launched by the former President Robert Mugabe. A total amount of USD24 million was pledged by the qualifying businesses as seed capital towards infrastructure development in these rural communities. It was established that fourteen CSOTs were now operational and 


\section{MInstitute Macrothink $_{\text {Int }}$}

implementing various developmental projects such as the construction of roads, hospitals, clinics and many others. Some of these Trusts had managed to provide goods and services to their respective communities to the tune of USD 5.25 million.

It was noted from the interviews and focus groups discussions that not even a single project had started off the ground in the Marange-Zimunya communities. This was due to the failure by companies operating in the two communities to honour their financial pledges. Only two companies (Anjin and DMC) had contributed USD200 000 each and the other three were yet to honour their pledges. It was revealed that these companies were resisting the move as they felt that the stake was too high.

All the traditional leaders in the area expressed concern over the lack of speed in the implementation of the controversial Marange-Zimunya Community Share Ownership Trust in which diamond mining companies in Manicaland pledged to pour \$10 million into the two communities. At the time of the study communities were still waiting anxiously for the funds to be released. In-depth interviews with traditional leaders revealed that two communities had presented a number of developmental project proposals for funding under the Community Share Ownership Trust but nothing was forth coming. Companies mining diamonds in Marange-Zimunya were Jinan, Anjin Investment, Marange Resources, Mbada Diamonds and Marange at the time of the study. Some of these companies indicated that they did not pledge to pay $\$ 10$ million apiece. Table 1 shows that only two companies, DMC and Anjin had managed to contribute USD200 000 each towards CSOTs. The other three companies had not contributed even a cent towards the empowerment of the two communities.

\subsection{Challenges}

From the findings of this study, it was found that the country did not benefit from the diamonds mined in Chiadzwa but were smuggled outside the country by the Chinese. It is against this background that the two communities wanted to demonstrate against the mining activities in which they were left poorer than before due to the environmental degradation that had left most of the land unsuitable for agricultural purposes. The focus groups also submitted that these organisations had failed to offer employment to the locals. The Bocha Community Development Trust (BCDT) and Chiadzwa Community Development felt that these companies had over changed them. In the process of mining, an estimated 100000 hectares of land was said to have been destroyed by these companies. 


\section{Al Macrothink}

Business and Management Horizons

ISSN 2326-0297

2018, Vol. 6, No. 2

Table 1. Pledges and payments made by the companies operating in Marange-Zimunya

Communities as at June 2015

\begin{tabular}{|c|c|c|c|c|c|c|c|c|}
\hline Province & District & Trust & Qualifying Business & $\begin{array}{c}\text { Pledge in } \\
\text { millions (000 } \\
000)\end{array}$ & $\begin{array}{l}\text { Release in } \\
\text { thousands } \\
\quad(000)\end{array}$ & $\begin{array}{l}\text { Projects \& } \\
\text { allocation }\end{array}$ & Value & Status \\
\hline Manicaland & Mutare & $\begin{array}{c}\text { Marange-Zimunya } \\
\text { CSOT }\end{array}$ & $\begin{array}{c}\text { Mbada Diamonds } \\
\text { Anjin } \\
\text { DMC } \\
\text { Marange Resources } \\
\text { Jinan }\end{array}$ & $\begin{array}{l}10 \\
10 \\
10 \\
10 \\
10\end{array}$ & $\begin{array}{c}\text { Nil } \\
200000 \\
200000 \\
\text { Nil } \\
\text { Nil }\end{array}$ & $\begin{array}{c}\text { Projects not yet } \\
\text { commenced. } \\
\text { Projects } \\
\text { identification in } \\
\text { progress. }\end{array}$ & Nil & Nil \\
\hline
\end{tabular}

Source: Reports from the Ministry of Youth, Indigenisation and Economic Empowerment.

The government and traditional leaders indicated that the new invasions of the minefields by illegal miners were affecting the smooth operations in the minefields. Since the local communities were not benefiting from the mining activities, the Centre for Natural Resources and Governance (CNRG) and Marange community members launched a petition to the government requesting the mining companies to stop mining activities in the area until there were guarantees that villagers would benefit from proceeds of the gems.

The proposal to set up a diamond beneficiation industry in the Province was said to be in limbo due to lack of a legal framework to set up such an enterprise. The idea of setting up the the enterprise was for value addition and beneficiation meant for exports. Another challenge was that it was expensive to put-up infrastructure and equipment since the precious mineral was said to be almost exhausted. The local leadership including traditional leaders indicated that there was youths unrest in the province and they had threatened to to storm the offices of the mining companies, the reason being that they had failed to uplift the youths' socio-economic status.

Even though there were claims by traditional leaders that the Chinese companies mining diamonds in the Marange fields of Manicaland province were looting the gems there was no evidence to support the claims. Senior government officials indicated that the country had lost an approximate of $\$ 13$ million in diamond underhand dealings. One other sticky issue was about the missing usd15 billion from diamonds sales. Traditional leaders and villagers indicated that they had not benefited from the mining companies which had more than a decade operating in the two communities. 


\section{Discussion of the Findings}

Even though there is evidence that some 58 CSOTs were established in some Rural Districts with companies exploiting natural resources, not all of them had contributed towards the empowerment of these communities. When these Trusts were officially launched by His Excellency, President Robert Mugabe, dummy cheques were presented. Even though a total amount of USD24 million was pledged by the qualifying businesses as seed capital towards socio-economic infrastructure development in these two communities very little was paid towards the CSOTs. However, it was relieving to note that some CSOTs in other areas had already started yielding positive results as evidenced by the construction of roads, hospitals, clinics and bridges. It was also noted that some of the trusts had managed to provide goods and services to their respective communities to the tune of USD 5.25 million which was a sign of development. This was found to be the opposite in the Marange-Zimunya communities whereby no single project had taken off the ground. The communities were still working on the project proposals and the funds contributed by the two companies were not adequate. The fact that some of the companies were disputing the fact that they pledged USD10 million apiece could mean that if they did it was under duress. This was supported by the former Minister of Youth, Indigenisation and Economic Empowerment who indicated that there were no written agreements between the Government and these companies to contribute USD10 million apiece. He further revealed that it was the Ministry's duty to implement Government policy. It should also be noted that a pledge is not binding and the Government cannot take the companies which fail to honour these pledges to the court of law. It is critical for the Government to keep on engaging these organisations so that they can at least pay something towards these communities. It could also be proper to request these companies to pay the amount they can afford than sticking to the USD10 million which could be too high considering the poor performance of the economy. If the Government continued to stick to the USDD10 million per company, the profitability and viability of these companies could be affected.

Even though no clear reasons were given by these companies for non-payment or late releases, this could be that the companies were not making profits as speculated by the stakeholders. If that is the case, it is prudent for the companies to declare their financial statements to the Government so that they come up with a common understanding. Even though there were some speculations that sales of diamonds were making a difference on the international markets, the fortunes of the country were not changing for the better. Lessons learnt from this were that policy consistencies were very critical in developing a nation. Had this policy been applied from 1980, the country could have been economically better off by now.

If foreign companies are compelled to pay such huge amounts of money, this is likely to discourage foreign direct investment which the country desperately needs to steer economic growth. If this issue is not properly addressed, it likely to affect the growth of the economy as many investors would shun Zimbabwe as a lucrative investment destination. Even though the majority of participants felt that it was a positive development to transfer part of the equity to serious local investors, this should be transparent and be done in an orderly manner. Table 1 shows that no meaningful contributions were made by the diamond companies in these 
communities. What is interesting is that it is always reported on news that Zimbabwe diamonds are making a difference on the international market yet the communities in which these diamonds are being mined are languishing in poverty. It is prudent for the Government to make sure that these companies fulfil their social responsibilities. Organisations which are environmentally friendly are likely to get new capital and repeated business deals. The fact that senior government officials and traditional leaders were worried with the late releases could be a sign that the programme was facing some resistance from the qualifying businesses. Failure by companies operating in the two communities to honour their pledges according to the traditional leaders was an issue of arrogance and non-compliance to Government directives. The state of infrastructure in provincial capital of Mutare does not show any improvements.

\section{Model of empowerment}

In order to address the issues raised, the researchers propose the Model of Empowerment (see Figure 1). If all the issues in the model are addressed, communities in Zimbabwe may realise total empowerment. The elements of the model are discussed in the following section.

$>$ Capital - these are start-up resources. Capital can be in any form. In the case of this paper, natural resource, which are the diamonds are key to both the investors and communities since they all benefit.

$>$ Land - this natural resource holds all other resources together. Sustainable utilisation of this natural resource is critical. The idea is for future generations to benefit from the same natural resources as well. Land degradation was raised as a major concern by the two communities

$>$ Entrepreneurship — can be regarded as a process of identifying and grabbing a business opportunity for future benefits. In the case of this study, the five companies operating in these two communities seized the opportunity of mining diamonds, which have a high market value.

$>$ Labour-labour drives the other factors of production. Employees are the ones who can make or break an organisation. What is positive from this study is that a few youths in these communities were employed to work in the mine-fields.

$>$ Community - these are the people who live in these communities and they are the presumed owners of the natural resources, therefore the idea of coming up with community ownership trusts and development projects and programmes.

$>$ Social responsibility - the idea of ploughing back to the communities in which they are doing business. Creating jobs, building schools, hospitals, roads and social amenities are critical in empowering the communities.

$>$ Total economic empowerment - this is when communities are economically empowered. It is only possible when all the issues discussed above are sincerely addressed. 


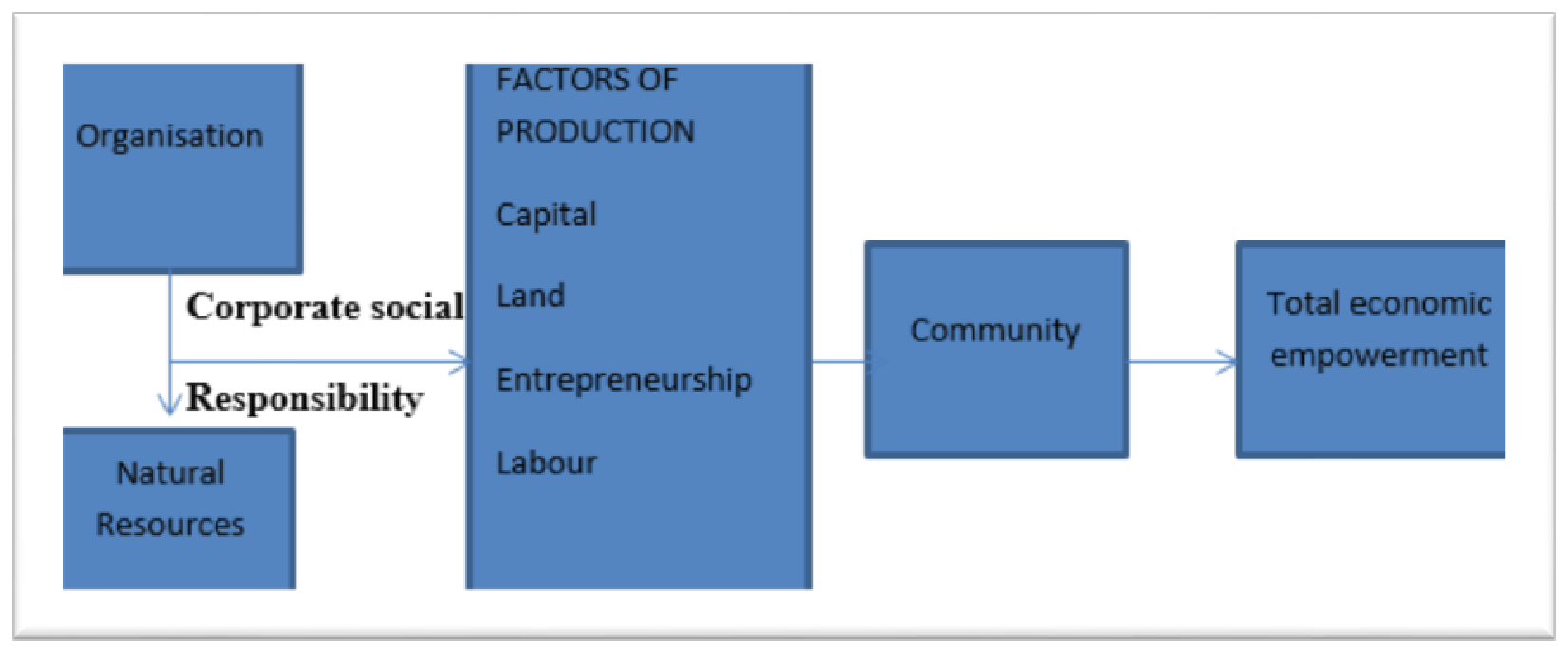

Figure 1. Empowerment model

Source: Field data.

\section{Recommendations}

The study recommended that organisations operating in the Marange-Zimunya communities should honour their pledges so that they continue to have the support of the Government and the communities in which they are operating. Giving back to the community is their social obligation. Since these companies have failed to honour their pledges on time, the Government should continue to engage these companies so that something positive comes out of it.

\section{Conclusion}

In conclusion, the idea of economically empowering marginalised communities is a noble one. It is a sign of good corporate citizenship on the part of the Government and good corporate governance on the part of the mining companies. The Government must take upon itself to make sure that the disadvantaged communities are empowered. It has been noted that most companies in Zimbabwe which are exploiting natural resources are doing business at the expense of local communities. Land degradation, water and air pollution are some of negative externalities caused by these companies. CSOTs can be the best option to compensate rural communities.

\section{References}

Debt Relief under the Heavily Indebted Poor Countries Initiative. (2015). Retrieved from https://www.imf.org/external/np/exr/facts/hipc.htm

Eshun, E. F. (2017). Peer assessment in graphic design studio: communication design students' perspectives. Journal of Science and Technology, 37(1), 64-74. https://dx.doi.org/10.4314/just.v37i1.6

Golla, A. M., Malhotra, A., Nanda, P., \& Mehra, R. (2011). Understanding and Measuring 
Women's Economic Empowerment. International Centre for Research on Women.

Gono, G. (2013). The consequences of implementing the current indigenisation framework on the banking sector. (Part 2). Reserve Bank of Zimbabwe. May 2013.

Indigenisation and Economic Empowerment Act Chapter 14:33/2008.

International Monetary Fund. (2007). Debt Relief Under the Heavily Indebted Poor Countries (HIPC) Initiative. Retrieved from http://www.imf.org/external/np/exr/facts/hipc.htm

Joseph, P. E. (2017). From political independence to economic emancipation: reseeding Africa with entrepreneurship and institutions to accelerate economic development. Transnational Corporations Review. https://dx.doi.org/10.1080/19186444.2017.1287825

Kanyenze, G., \& Kondo, T. (2011), Beyond the Enclave: Towards a Pro-Poor and Inclusive Development for Strategy for Zimbabwe: Weaver Press.

Magura, B. (2013) Land, Indigenisation and Empowerment: Narratives that Made a Difference in Zimbabwe's 2013 Elections. Journal of African Elections, 13(2).

Makina, D. (2009). Recovery of the Financial Sector and Building Financial Inclusiveness. UNDP Comprehensive Economic Recovery in Zimbabwe Working Paper Series.

Marazanye, K. (2016). An analysis of the indigenisation and economic empowerment in Zimbabwe. Thesis presented impartial fulfilment of the requirement for the degree of Masters in Public Administration, Stellenbosch University.

Matthew, O., \& Gidigbi, M. O. (2017). An Assessment of the Impact of Banking Reforms on Economic Growth and Bank Performance in Nigeria. CBN Journal of Applied Statistics, 8(2), 143.

Mawowa, S. (2013). Community Share ownership Trusts (CSOT) in Zimbabwe's Mining Sector: The Case of Mhondoro-Ngezi. Zimbabwe Environmental Law Association.

Mereko, K. (2017). Political power, economic emancipation and serial spectators. Joburg Post.

Mtomba, V. (2016). Indigenization now a mess-The Zimbabwe Independent. (2014). The Zimbabwe Situation. Retrieved from https://www.thestandard.co.zw/2016/03/27/zims-indigenisation-mess/

Munzara, A. T. (2015). The Consequences of Implementing the Indigenisation and Economic Empowerment Policy Framework on the Banking Sector in Zimbabwe. IOSR Journal of Business and Management, 17(11), 55-57.

Phillip, K. (2011). How the structure of the economy impacts on opportunities on the margins. Retrieved from http://www.tips.org.za/files/u65/how_the_structure_of_the_economy_impacts_on_the_oppor tunities_on_the_margins_-_phillip.pdf

Shava, E. (2016). Black Economic Empowerment in South Africa: Challenges and Prospects. 


\section{Macrothink}

Business and Management Horizons

ISSN 2326-0297

2018, Vol. 6, No. 2

Journal of Economics and Behavioral, 8(6), 161-170.

South Africa Economy Watch. (2008). Chinese are declared to be Black, so are Chinese Fully Black? BEE Partner.

The Economist. (2007). How to stay alive when it all runs out.

World Bank. (2006). Zimbabwe Budget 2006. Retrieved from http://www.zimbabwesituation.com/jul28b_2006.html\#Z2

Zimbabwe Agenda for Sustainable Socio-Economic Transformation. (2013). Government Printers, Harare, Zimbabwe.

Zimbabwe National Statistics Agency. (2015). Facts and Figures. Retrieved from http://www.zimstat.co.zw/sites/default/files/img/publications/Prices/Fact_2015.pdf

\section{Copyrights}

Copyright for this article is retained by the author(s), with first publication rights granted to the journal.

This is an open-access article distributed under the terms and conditions of the Creative Commons Attribution license (http://creativecommons.org/licenses/by/4.0/). 